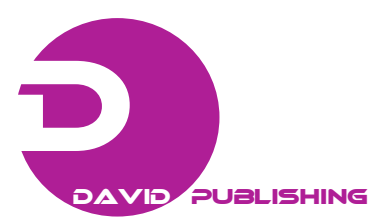

\title{
Producing Arabic Bread Enriched with Minerals and
}

\section{Protein}

\author{
Mustafa Satouf and May Al-Kateb \\ Food Engineering Department, Petrochemical Engineering Faculty, AL-Baath University, Homs, Syria
}

Received: October 25, 2011 / Published: July 20, 2012.

\begin{abstract}
This research aims to produce Arabic bread enriched with iron, zinc, copper, magnesium and protein by the addition of ingredients such as parsley powder, oats, grape seeds, soybean meal, wheat germ, and milk powder. In this study, for enriched bread samples sensory evaluation, chemical and mineral composition determination and microbiological tests were carried out. The sensory evaluation of breads showed that both mixtures, which were enriched with grape seeds, oats, and wheat germs, have excellent quality. The chemical tests showed that the enriched breads have high fat, ash, fiber, and protein when compared with normal Arabic bread. It was noticed that the consumption of three enriched Arabic bread loaves gives us about $78.9 \%$ from our daily need of zinc, whereas the unenriched bread gives us only $48.8 \%$, about $82.2 \%$ from our daily needs of copper, whereas the normal bread gives us only $58.8 \%$, and $93.9 \%$ from our daily need of iron, whereas the normal bread gives us only $71.2 \%$.
\end{abstract}

Key words: Arabic bread, enrichment, minerals, oats, grape seeds, parsley.

\section{Introduction}

Bread is a staple food for many people. It is particularly important in diets of people of the Middle East region and the Indian subcontinent, for instance, bread consumption is $130 \mathrm{~kg} /$ year in Syria. Arabic bread is the most common double layered flatbreads [1].

Wheat is the principle raw material used to produce flour for Arabic bread. The important nutrients content in the flour is less than in wheat. During the milling process, refined grains retain only the starchy endosperm. Products of refined cereal grains such as white flour, include neither the bran which is rich in B vitamins, unsaturated fatty acids, phytochemicals such as flavonoids, indoles, phyto-oestrogens and fibre, nor the germ that has an abundance of minerals such as Fe, $\mathrm{Zn}, \mathrm{Mg}, \mathrm{Ca}, \mathrm{S}$ and $\mathrm{Zn}$ as well as the antioxidant vitamin E. The removal of bran and germ results in a substantial loss of important nutrients [2].

Flour fortification is not just good to have: it is

Corresponding author: Mustafa Satouf, Ph.D., researcher, research field: enriching arabic bread. E-mail: mrksham@gmail.com. essential for the health of populations. That is because more than 2 billion people in the world today, nearly all of them in developing countries, suffer from nutritional deficiencies [3].

Good diet, a healthy lifestyle, and exercise are essential for a healthy immune system that protects against invasion by bacteria, viruses, parasites and fungi. We can not continue to rely on antibiotics to save us. The rise of "super-bugs" like MRSA (Methicillin-resistant Staphylococcus aureus), C. difficile, VRSA (Vancomycin-resistant S. aureus) and Multiple Drug Resistant Tuberculosis indicates that many antibiotics are losing their effectiveness, as antibiotic resistance continues to increase [4].

There is not any natural food containing all nutrient elements, so a lot of people consume functional food, which performs a specific role in the body. They are not pills or supplements, but everyday food. Functional foods are similar in appearance to conventional foods and are intended to be consumed as part of a normal diet, but have been modified to subserve physiological roles beyond the provision of simple nutrient 
requirements [5].

Fortifying staple foods is the cheapest, most efficient and most effective way to supply large populations with essential micronutrients. Bringing the technology to fortify staple foods such as flour, salt, oil and condiments such as soy sauce to developing countries is a cost effective solution to micronutrient deficiency, especially when undertaken in tandem with broader national strategies that improve overall nutritional status. Food fortification does not require people to change their existing dietary habits, and because staple foods such as bread or noodles are used daily, and are part of the diets of even the poorest, fortification has the potential in a short period of time to reach millions of people around the world with micronutrients on a daily basis [3].

Soybean is an excellent source of protein (35\%-40\%), hence the seed is the richest in food value of all plant foods consumed in the world. It is used in the fresh, fermented or dried form. It is also rich in calcium, iron, phosphorus and vitamins. It is the only source that contains all the essential amino acids. Its use in the production of bread as composite flour has been reported [6].

Fortification of wheat flour with oat flour, improves the nutritional quality of the composite flours. Oat bran, possibly by virtue of its $\beta$-glucan content, exerts potential beneficial physiological activity when consumed as part of the human diet. Chronic disease conditions, such as diabetes, atherosclerosis and digestive diseases, appear to be improved by inclusion of more fibre in the diet. The important nutritional attributes of oats relate to the lowering of blood cholesterol and sugar. Oat contains a high percentage of desirable complex carbohydrates which have been linked to reduced incidence of different kinds of cancers. The presence of total and free sugars in oats is very low in comparison to other cereal grains. Oats contain the best amino acid composition profile among all the cereal grains in addition to an overall high protein content. Oat protein is uniquely different from other cereals. The major protein fraction in oats is the salt-soluble globulin, which is probably the primary reason for the better nutritive value of oats. The higher level of lysine in the globulin fraction than in the glutelin and prolamin fractions causes the better nutrient value of oats [7].

The base line for nutrient content of all wheat products which are high in proportion of flour depends largely on the nutrient content of the flour. Today's higher extraction rates for flour have influenced the content of several important nutrients [8].

Functional ingredient must be able to be incorporated into bread. They should be added at a level sufficient to achieve the intended effect. It must be dispersed evenly throughout the dough, and able to survive through the baking process and retain its physiological activity. It must survive during the normal shelf life of the product. Final product quality and acceptability should be maintained [9].

\section{Materials and Methods}

This study was performed using wheat flour with $70 \%$ extraction rate and the other materials which were used to enrich the produced bread were ground and prepared as ingredient Oat grain and soybean were milled by laboratory mill (Sweden, Perten3303). Grape seeds and the parsley were air-dried and milled by using coffee mill. Dried milk was defatted. Raw wheat germ was toasted $\left(135{ }^{\circ} \mathrm{C}, 20 \mathrm{~min}\right)$.

\subsection{Chemical Tests}

The moisture content was determined by ICC, Standard 1976, No: 110/1. Proteincontent was determined by ICC, Standard 1980, No: 105/1. Ash content was determined by ICC, Standard 1960, No: 104. Crude fibre content was determined by Weender Method. Fat content was determined by Method 02-01 A (AACC, 1999).

\subsection{Microbiological Tests}

Ten grams of each sample were taken aseptically and 
homogenized in $90 \mathrm{~mL}$ sterile distilled water in a blender (AES Laboratory) for about $2 \mathrm{~min}$. Serial dilutions (using $1 \mathrm{~mL}$ of homogenates) were made in 9 $\mathrm{mL}$ sterile distilled water, dispensed in test tubes. One millilitre of each dilution was pour plated in sterile Petri dishes. The total microbial count was determined using plates of Plate Count Agar, the molds and yeasts were determined using plates of sabouraud, Salmonella was determined on S-S Agar, and Staphylococcus was determined using plates of Baird Parker Agar. Plates were incubated at $37{ }^{\circ} \mathrm{C}$ for $48 \mathrm{~h}$ in an incubator (Heavaerus Instruments), except Sabouraud plates which were incubated at $28{ }^{\circ} \mathrm{C}$ for 5 days. Counts of colonies were determined using Selecta instrument [12].

\subsection{Definition of Metal Elements}

Copper, iron, magnesium and zinc contents were determined by Atomic absorption instrument (AVANTA-3000) according to the approved method40-70 (AACC, 1999).

\subsection{Preparation of Bread Samples}

Wheat flour was fortified with protein, copper, iron magnesium, and zinc depending on average daily need of them (Table 1), using food ingredients such as parsley powder, oats, grape seeds, soybean meal, wheat germ, and milk powder instead of minerals.

The following materials were added to enrich the bread with the needed elements and as they are easy to be added to the dough:

Soybean meal was added as a source of $\mathrm{Mg}$ (255 $\mathrm{mg} / 100 \mathrm{gr}), \mathrm{Zn}(2 \mathrm{mg} / 100 \mathrm{gr}), \mathrm{Fe}(8 \mathrm{mg} / 100 \mathrm{gr})$ and protein $(40 \%)$ [13].

Defatted dried milk was added as a source of $\mathrm{Mg}$ $(100 \mathrm{mg} / 100 \mathrm{gr})$ and protein (36.2\%) [13].

Oat meal was added as a source of $\mathrm{Mg}(138 \mathrm{mg} / 100$ gr), $\mathrm{Zn}(3 \mathrm{mg} / 100 \mathrm{gr}), \mathrm{Fe}(6.2 \mathrm{mg} / 100 \mathrm{gr})$ and $\mathrm{Cu}(0.5$ $\mathrm{mg} / 100 \mathrm{gr})[14]$.

Parsley powder was added as a source of Fe (17.9 $\mathrm{mg} / 100 \mathrm{gr}$ ) [13].
Table 1 Average daily need for minerals and protein.

\begin{tabular}{lcccc}
\hline Protein & $\mathrm{Fe}$ & $\mathrm{Zn}$ & $\mathrm{Mg}$ & $\mathrm{Cu}$ \\
\hline gr/kg $(\mathrm{BW})$ & \multicolumn{4}{c}{$\mathrm{mg} / \mathrm{day}$} \\
0.75 & 12 & 15 & 315 & 2 \\
\hline
\end{tabular}

Grape seeds powder was added as a source of $\mathrm{Mg}$ (105.43 mg/100 gr) and Fe (33.57 mg/100 gr) [15].

Raw wheat germ was added as a source of $\mathrm{Zn}$ (11.21 $\mathrm{mg} / 100$ gr), this concentration was determined by atomic absorption instrument.

Depending on the proportions of metals and protein in each additive and depending on the daily requirement of each element, authors studied the theoretical value for a number of many mixtures and then chose the best mixtures in terms of securing all the elements in a balanced manner. Table 2 shows the content of studied mixtures.

Consumption of three loaves of enriched bread theoretically provides us with $\mathrm{Zn}, \mathrm{Fe}, \mathrm{Mg}, \mathrm{Cu}$ and protein as shown in Table 3.

\subsection{Sensory Evaluation}

The sensory attributes were evaluated by a semi trained 5-member panel according to Kenneth and Quail [1] (Table 4). Overall bread scores are considered excellent from 81-100, good from 76-80, acceptable from 70-75 and unsatisfactory below 70 .

\subsection{Statical Analysis}

All statistical analysis were performed using the procedures of the Minitab software system [13].

\section{Results and Discussion}

The results for chemical composition tests of raw materials are demonstrated in Table 5.

Wheat flour contains $0.650 \%$ ash, protein $11.6 \%$, fat $2.1 \%$, fiber $0.2 \%$ and these results converge with the researchers Salehifar et al. [7] and Kenneth et al. [1] who explained that flour contains $0.450 \%$ ash, $11.0 \%$ protein, $1.9 \%$ fat, and fiber $<0.5 \%$.

Grape seeds meal contains $3.361 \%$ ash, protein $12.6 \%$, fat $10.7 \%$, and fiber $44.4 \%$ and these results 
Table 2 Content of ingredients in studied mixtures.

\begin{tabular}{|c|c|c|c|c|c|c|c|c|c|}
\hline Material & Flour & $\begin{array}{l}\text { Total weight } \\
\text { (3 loaves) }\end{array}$ & $\begin{array}{l}\text { Wheat } \\
\text { flour }\end{array}$ & $\begin{array}{l}\text { Parsley } \\
\text { powder }\end{array}$ & Grape seed & Dried milk & Oat meal & $\begin{array}{l}\text { Wheat } \\
\text { germ }\end{array}$ & Soy meal \\
\hline Mixture & $\%$ & gr & & & & & & & \\
\hline 1 & 50 & 450 & 225 & 50 & - & 18.8 & - & 81.3 & 75 \\
\hline 2 & 60 & 450 & 270 & 37.5 & - & 12.5 & - & 68.8 & 62.5 \\
\hline 3 & 70 & 450 & 315 & 35 & - & - & - & 56.3 & 43.8 \\
\hline 4 & 70 & 450 & 315 & - & 25 & - & 62.5 & 50 & - \\
\hline 5 & 60 & 450 & 270 & - & 25 & - & 75 & 82.5 & - \\
\hline 6 & 60 & 450 & 270 & - & 37.5 & - & - & 142.5 & - \\
\hline
\end{tabular}

Table 3 Theoretical value of studied mixtures.

\begin{tabular}{lllllll}
\hline & & Protein & \multicolumn{5}{c}{$\mathrm{Mg}$} & $\mathrm{Zn}$ & $\mathrm{Fe}$ & $\mathrm{Cu}$ \\
\cline { 3 - 6 } Mixture & & \multicolumn{5}{c}{ \% of Daily Need } \\
2 & 132.9 & 154.5 & 97.7 & 139.6 & - \\
3 & 129 & 162.5 & 92.1 & 115.6 & - \\
4 & 115.5 & 164.2 & 85.7 & 102.4 & \\
5 & 92.8 & 159.5 & 88.9 & 112.3 & 6.4 \\
6 & 84.6 & 144.5 & 61.6 & 113.6 & 7.7 \\
\hline
\end{tabular}

Table 4 Scoring system for Arabic bread.

\begin{tabular}{lrlr}
\hline Character & Score & Character & Score \\
\hline First Day & & Crumb texture & 5 \\
Size & 5 & Crumb appearance & 5 \\
Shape & 5 & Evenness of Layers & 5 \\
Smoothness/cracks & 5 & Tearing & 10 \\
Crust colour & 5 & Day Two & \\
Blisters & 5 & Rolling and Folding & 20 \\
Rolling and Folding & 10 & Tearing & 10 \\
Pocketing & 10 & Total & 100 \\
\hline
\end{tabular}

Table 5 Chemical composition of raw materials*.

\begin{tabular}{lrrrrrl}
\hline Properties & Moisture & Ash & Protein & Fat & Fiber & Zn mg \\
\cline { 2 - 6 } Material & \multicolumn{5}{c}{$\%$} \\
\hline Wheat Flour & 13.2 & 0.650 & 11.6 & 2.1 & 0.2 & - \\
Oat Meal & 10.4 & 3.720 & 10.4 & 7.7 & 5.9 & - \\
Wheat Germ & 14.2 & 3.448 & 19.9 & 7.5 & 4.7 & 11.207 \\
Grape Seeds & 7.2 & 3.361 & 12.6 & 10.7 & 44.4 & - \\
\hline
\end{tabular}

*All samples were analyzed in duplicate.

converge with the researchers. El-Bastawesi et al. [15] who explained that grape seeds meal contains $3.864 \%$ ash, $13.0 \%$ protein, $14.9 \%$ fat, and $32.7 \%$ fiber [14].

It was noticed that wheat germ is rich in protein $19.9 \%$ and $\mathrm{Zn} 11.207 \mathrm{mg} / 100 \mathrm{gr}$ and its contents of fat $7.7 \%$, ash $3.448 \%$ and fiber $4.7 \%$ are more than wheat flour contents. Wheat germ used in this research is not pure. Because pure wheat germ is expensive.
Results of sensory evaluation of studied enriched bread are summarized in Table 6, mixtures 1, 2, 6 gave unacceptable Arabic bread in terms of sensory properties because the overall scores are 41.4, 63.8, 60.2 respectively. Statistical analysis indicates that there are significant differences $(P \leq 0.05)$ between overall scores of bread made from mixes 1, 2, 6 and overall scores of control bread.

Mixture 3 gives acceptable Arabic bread in terms of sensory properties because the overall scores are 73.8. Statistical analysis indicates that there are significant differences $(P \leq 0.05)$ between overall scores of bread made from mix 3 and overall scores of control bread.

Mixtures 4 and 5 give excellent Arabic bread in terms of sensory properties because the overall scores are 93.0 and 90.6 respectively. Statistical analysis indicates that there are no significant differences $(P \leq$ 0.05 ) between overall scores of bread made from mixes 4, 5 and overall scores of control bread.

Mixtures 4 and 5 were selected to continue this research depending on the results of sensory evaluation of produced bread, also mixture 6 was selected because it contains high concentration of $\mathrm{Fe}(122.9 \%)$ and $\mathrm{Zn}$ (138.9\%) as shown in Table 3.

The chemical composition of studied bread samples are demonstrated in Table 7.

Enriched Arabic bread samples No.4, No.5 and No.6 contain ash (respectively 3.016\%, 3.318\%, 2.913\%) more than the ash content of control Arabic bread sample $1.779 \%$ and this result converges with the researcher Olaoye [6] who explained that Arabic bread sample produced of $85 \%$ wheat flour and $15 \%$ soybean 
Table 6 Sensory evaluation of enriched bread*.

\begin{tabular}{|c|c|c|c|c|c|c|c|}
\hline \multirow{2}{*}{ Mixture } & \multicolumn{5}{|c|}{ Member } & \multirow{2}{*}{-Mean \pm SD } & \multirow{2}{*}{ Scores } \\
\hline & 1 & 2 & 3 & 4 & 5 & & \\
\hline 1 & 52 & 39 & 35 & 46 & 35 & $41.4^{\mathrm{a}} \pm 7.44$ & Unsatisfactory \\
\hline 2 & 64 & 78 & 67 & 56 & 54 & $63.8^{\mathrm{b}} \pm 9.60$ & Unsatisfactory \\
\hline 3 & 65 & 71 & 71 & 85 & 77 & $73.8^{\mathrm{b}} \pm 7.56$ & Acceptable \\
\hline 4 & 90 & 93 & 90 & 98 & 94 & $93.0^{\mathrm{cd}} \pm 3.32$ & Excellent \\
\hline 5 & 95 & 88 & 87 & 90 & 93 & $90.6^{\mathrm{c}} \pm 3.36$ & Excellent \\
\hline 6 & 68 & 62 & 69 & 70 & 65 & $60.2^{\mathrm{b}} \pm 5.67$ & Unsatisfactory \\
\hline Control & 98 & 95 & 100 & 95 & 97 & $97.0^{\mathrm{d}} \pm 2.12$ & Excellent \\
\hline
\end{tabular}

*Same letters mean no significant difference at $P \leq 0.05$.

Table 7 Chemical composition of studied bread samples*.

\begin{tabular}{llllll}
\hline $\begin{array}{l}\text { Properties } \\
\text { Sample }\end{array}$ & Moisture & Ash & Protein & Fat & Fiber \\
\cline { 2 - 6 } & \multicolumn{5}{c}{$\%$} \\
\hline Control & 28.6 & 1.779 & 15.7 & 0.8 & 0.05 \\
Bread No. 4 & 29.3 & 3.016 & 15.9 & 2.10 & 3.1 \\
Bread No. 5 & 29.0 & 3.318 & 15.4 & 2.51 & 3.1 \\
Bread No. 6 & 25.5 & 2.913 & 17.1 & 2.27 & 3.2 \\
\hline
\end{tabular}

* All samples were analyzed in duplicate.

* Bread No.4 indicates to the bread which produced from mixture 4 .

flour contains ash $1.17 \%$ higher than the content of unenriched Arabic bread 0.64\%[6].

Enriched Arabic bread samples No.4, No.5 and No.6 contain fiber (respectively $3.1 \%, 3.1 \%, 3.2 \%$ ) more than the fiber content of control Arabic bread sample $0.05 \%$.

Enriched Arabic bread samples No.4, No.5 and No.6 contain fat (respectively $2.10 \%, 2.51 \%, 2.27 \%$ ) more than the fat content of control Arabic bread sample $0.8 \%$ and this result converges with the researcher Olaoye [6] who explained that Arabic bread sample produced of $85 \%$ wheat flour and $15 \%$ soybean flour contains fat $2.46 \%$ higher than the fat content of unenriched Arabic bread $0.76 \%$.

The high content of ash, fat and fiber in enriched Arabic bread samples No.4, No.5 and No.6 as compared with control Arabic bread can be attributed to adding high amount of oat, wheat germ and grape seeds and their chemical composition is demonstrated in Table 6.

Enriched Arabic bread sample No.6 contains protein $17.1 \%$ more than the protein content of enriched
Table 8 Metal elements concentrations in studied arabic bread samples*.

\begin{tabular}{lllll}
\hline Element & $\mathrm{Zn}$ & $\mathrm{Cu}$ & $\mathrm{Fe}$ & $\mathrm{Mg}$ \\
\cline { 2 - 5 } Sample & \multicolumn{4}{c}{$\mathrm{ppm}$} \\
\hline Control & 16.296 & 2.942 & 19.011 & 188.303 \\
4 & 19.427 & 2.747 & 23.155 & 234.410 \\
5 & 20.384 & 3.610 & 23.233 & 233.560 \\
6 & 26.317 & 4.112 & 25.055 & 227.398 \\
\hline
\end{tabular}

*All samples were analyzed in duplicate.

Arabic bread samples No.4 and No.5 (respectively $15.9 \%, 15.4 \%$ ), and that can be attributed to adding high amount of wheat germ (31.67\%) to mixture 6 .

Metal elements concentrations in studied Arabic bread samples are summarized in Table 8 .

Enriched Arabic bread samples No.4, No.5 and No.6 contain Zn (respectively 19.427 ppm, 20.384 ppm, $26.317 \mathrm{ppm}$ ) more than $\mathrm{Zn}$ content of control Arabic bread sample $16.296 \mathrm{ppm}$, and it can be attributed to adding wheat germ which contains high percentage of Zn.

Concentrations of magnesium in enriched Arabic bread samples No.4, No.5 and No.6 (respectively $234.410 \mathrm{ppm}, 233.560 \mathrm{ppm}, 227.398 \mathrm{ppm}$ ) are more than control Arabic bread sample (188.303 ppm).

Enriched Arabic bread samples No.4, No.5 and No.6 contain Fe (respectively 23.155 ppm, 23.233 ppm, $25.055 \mathrm{ppm})$ more than $\mathrm{Fe}$ content of control Arabic bread sample $19.011 \mathrm{ppm}$, and it can be attributed to adding grape seeds meal which is rich in Fe.

Concentrations of $\mathrm{Cu}$ in enriched Arabic bread samples No.5 and No.6 (respectively 3.610 ppm, 4.112 ppm) are more than control Arabic bread sample (2.942 
ppm), and it can be attributed to high percentage of $\mathrm{Cu}$ in oat and wheat germ which were added to samples No.5 and No.6.

Table 9 shows the metal elements which can be provided by consumption three loaves of enriched Arabic bread a day, as a percentage of the daily requirement of each element.

Enriched Arabic bread samples No.4, No.5 and No.6 give a greater percentage of daily requirements of $\mathrm{Zn}$, $\mathrm{Fe}$ and $\mathrm{Mg}$ as compared with control Arabic bread.

The microbiological results of the three enriched Arabic bread samples are demonstrated in Table 10.

The results for Salmonella, Total microbial count, staphylococcus, molds and yeasts are in conformity with Syrian standard specification 2197/2007, that the bread samples are free of Salmonella and Staphylococcus, and total microbial count is below the established limit.

The microbiological results indicate that studied bread samples containmolds and yeasts, and this is incompatible with the Syrian standard specification which states that bread should be free of molds and yeast. That can be attributed to the use of 3.5\% fresh yeast, and this was confirmed by the absence of placenta with the cells shown on the plate after five days, and because their smell, color and brightness are similar to those of yeast bread. This was confirmed by placing bread samples in airtight bags under normal atmospheric temperature for three days and no mold or abnormal change was noticed.

\section{Conclusions}

The results of sensory evaluation indicate that the grape seeds are more suitable for enriching Arabic bread with iron than Parsley powder. For the chemical composition, enriched Arabic bread samples contain a high proportion of fat, ash, fiber and protein as compared with control Arabic bread. The daily consumption of three loaves of Arabic bread enriched with grape seeds, wheat germ and oat provides us with approximately $78.9 \%$ of the daily requirement of Zinc,
Table 9 Metal elements provided by consumption three loaves a day*.

\begin{tabular}{|c|c|c|c|c|}
\hline Sample Element & Control & No.4 & No.5 & No.6 \\
\hline $\mathrm{Zn}$ & 48.87 & 58.28 & 61.15 & 78.95 \\
\hline$\%$ daily & 58.84 & 54.94 & 72.19 & 82.24 \\
\hline requirement & 71.29 & 86.83 & 87.24 & 93.96 \\
\hline $\mathrm{Mg}$ & 33.89 & 42.19 & 42.04 & 40.93 \\
\hline
\end{tabular}

*All samples were analyzed in duplicate.

Table 10 Microbiological results of Arabic bread samples.

\begin{tabular}{lllll}
\hline Test sample & $\begin{array}{l}\text { Total } \\
\text { microbial } \\
\text { count }\end{array}$ & Salmonella Staphylococcus & $\begin{array}{l}\text { Molds and } \\
\text { yeasts }\end{array}$ \\
\cline { 2 - 5 } & & CFU/g & \\
\hline Bread No. 4 & $5.3 \times 10^{2}$ & Free & Free & $2.3 \times 10^{2}$ \\
Bread No.5 & $2.5 \times 10^{2}$ & Free & Free & $6.1 \times 10^{2}$ \\
$\begin{array}{l}\text { Control No.6 } \\
\text { Syrian standard }\end{array}$ & $1.9 \times 10^{2}$ & Free & Free & $4.2 \times 10^{2}$ \\
specification & $10^{4}$ & Free & Free & Free \\
\hline
\end{tabular}

$82.2 \%$ of the daily requirement of Copper, and $93.9 \%$ of the daily requirement of Iron.

\section{References}

[1] J. Kenneth, P.D. Quail, Arabic Bread Production, AACC. Inc. St. Paul, Minnesota, USA, 1996, pp. 1-147.

[2] C.R. Giha, C. Lamprinopoulou, L. Toma, B.K. Teahan, P. Leat, L. Cacciolatti, Cereal prices, bread consumptionand health in scotland, in: The 83rd Annual Conference of the Agricultural Economics Society, 2009, pp. 1-20.

[3] A. Verster, Food fortification: Good to have or need to have? J. of Eastern Mediterranean Health 10 (6) (2004) 771-777.

[4] G. Daily, P.R. Ehrlich, Global change and human susceptibility to disease, Annu. Rev. Energy Environ, 21 (1996) 125-144.

[5] J. Bradbury, T. Lobstein, V. Lund, Functional Foods Examined, The Food Commission London EC2A 2BH, 1996, p. 78.

[6] O.A. Olaoye, A.A. Onilude, O.A. Idowu, Quality characteristics of bread produced from composite flours of wheat, Plantain and Soybeans, African Journal of Biotechnology 5 (11) (2006) 1102-1106.

[7] M. Salehifar, M. Shahedi, Effects of flour on dough rheology, texture and organoleptic properties of taftoon bread, J. Agric. Sci. Technol. 9 (2007) 227-234.

[8] R.H. Matthews, M.Y. Workman, Nutrient composition of selected wheat product, Cereal Chem 54 (5) (1976) 1115-1123.

[9] Bread and Health: Opportunities and issues by Gareth Edwards [Online], http:// novelfoods.co.uk. 
[10] Anonymous, International Association for Cereal Chemistry ICC Standards, Vienna, Austria, 1982.

[11] Anonymous, AACC Standard, American Association of Cereal Chemists, AACC Approved Method, AACC, St. Paul, MN, 1999.

[12] M.O. Fawole, B.A. Oso, Laboratory Manual in Microbiology, 3rd ed., Spectrum Books Ltd., Ibadan, 2001.

[13] G. Ganji, Nutrition and Human Health, AL-Baath University, Food Engineering Department, Petrochemical Engineering Faculty, Syria, 2007, p. 399.

[14] H. Almanea, Techniques of Grain, King Saud University,
The Kingdom of Saudi Arabia, 1999, p. 686.

[15] A.M. El-bastawesi, A.A. El-Refai, M.M. Zakaria, Grape and mango seeds as untraditional sources of edible oils, antioxidants and antibacterial compounds, in: The first International Conference of Food Industries and Biotechnology, Syria, 2008.

[16] L.R. Jaisingh, Exploration Statistics with Data and the Minitab Windows Program Version 14.0, Mathematical Sciences Department, Morehead State University.

[17] Syrian Standard Specification, Microbiological Requirements for that Should be Achieved in the Bread, Syrian Arab Republic, 2007, No. 2197. 